\title{
Potassium Rate and Application Effect on Flue-Cured Tobacco
}

\author{
Matthew C. Vann,* Loren R. Fisher, David L. Jordan, W. David Smith, \\ David H. Hardy, and Alexander M. Stewart
}

\begin{abstract}
Research was conducted at two locations in 2009 and 2010 to evaluate the effect of various $\mathrm{K}$ rates and application methods on the yield and quality of flue-cured tobacco (Nicotiana tabacum L.). Treatments included five rates of K from sulfate of potash magnesia (0-0-22): 0, 84, 140, 196, and $252 \mathrm{~kg} \mathrm{~K}_{2} \mathrm{O} \mathrm{ha}{ }^{-1}$ that were applied: broadcast 1 mo before transplanting, broadcast 1 wk before transplanting, banded at transplanting, and a split application with one-half rate banded at transplanting followed by one-half rate banded at layby. Tissue samples were collected throughout the season at three separate growth stages: layby, topping, and after curing. Tissue samples were analyzed for total alkaloid and reducing sugars, N, P, K, and Mg content. Soil samples were collected the same day as K fertilizer application from plots not receiving supplemental K. Data were subjected to ANOVA using the PROC GLM procedure in SAS. Treatment means were separated using Fisher's Protected LSD test at $p \leq 0.05$. Application method and timing had no effect on any measured parameters; furthermore, crop yield and quality was not affected by $\mathrm{K} \mathrm{rates}>\mathrm{kg} \mathrm{K}_{2} \mathrm{O}$ ha ${ }^{-1}$ at three of four locations. It is likely that early broadcast applications of $\mathrm{K}_{2} \mathrm{O}$ with current rate recommendations would only be of concern with combinations of conditions that included coarse soil textures, low $\mathrm{K}$ indices, and/or excessive leaching rainfall.
\end{abstract}

P OTASSIUM FERTILIZER IS essential to the production of high yielding, high quality flue-cured tobacco, with a healthy crop typically requiring roughly $100 \mathrm{~kg} \mathrm{~K}_{2} \mathrm{O} \mathrm{ha}^{-1}$ from the soil for optimum growth (Raper and McCants, 1967). Tobacco, in general, is considered to be a luxury consumer of $\mathrm{K}^{+}$(Raper and McCants, 1967), and K application is often two to three times that needed to obtain maximum yield (Sims, 1985). Furthermore, K deficiencies have long been observed across a variety of soil types and growing conditions, and the overapplication of $\mathrm{K}$ fertilizer has been justified on the belief that deficiencies would be avoided and leaf and burn quality would improve (Collins and Hawks, 1993). Overapplication has traditionally been possible because of low input costs for fertilizers and liming materials; however, in recent years certain aspects of production have altered how tobacco producers address crop nutrition.

The first major issue is the cost of fertilizer inputs, specifically $\mathrm{K}$, which has increased by $292 \%$ since the year 2000 (Huang, 2012). As a result of increasing $\mathrm{K}$ prices, overapplication of fertilizer is no longer an option and growers must become more efficient in making applications. Second, nearly $85 \%$ of all traditional tobacco producing soils have a high (Mehlich-3 P $61-120 \mathrm{~g} \mathrm{P} \mathrm{m}^{-3}$ ) or

M.C. Vann, L.R. Fisher, and D.L. Jordan, Dep. of Crop Science, North Carolina State Univ., 101 Derieux Place, Raleigh, NC 27695-7620; W.D. Smith, Associate Dean for Research, North Carolina State Univ., 201 Patterson Hall, Raleigh, NC 27695-7643; D.H. Hardy, Agronomic Division, North Carolina Dep. of Agriculture and Consumer Services, 4300 Reedy Creek Rd, Raleigh, NC 27607-6465; A.M. Stewart, Research Station Division, North Carolina Dep. of Agriculture and Consumer Services, 2 W. Edenton Street, Raleigh, NC 27601. Received 10 July 2012. ${ }^{*}$ Corresponding author(matthew_vann@ncsu.edu).

Published in Agron. J. 105:304-310 (2013)

doi:10.2134/agronj2012.0259

Copyright (c) 2013 by the American Society of Agronomy, 5585 Guilford Road, Madison, WI 53711. All rights reserved. No part of this periodical may be reproduced or transmitted in any form or by any means, electronic or mechanical, including photocopying, recording, or any information storage and retrieval system, without permission in writing from the publisher. very-high (Mehlich-3 P > $120 \mathrm{~g} \mathrm{P} \mathrm{m}^{-3}$ ) P index (Hardy et. al., 2012; Smith, 2011). Years of overapplication of $P$ have led to high $\mathrm{P}$-indices and additional $\mathrm{P}$ is not required on most tobacco soils (Smith, 2011). Producers are now able to decouple N, P, and K, and move away from complete fertilizers which have traditionally been used. With independent applications of $\mathrm{N}$ and $\mathrm{K}$ producers now have more alternatives for sources and application methods of both nutrients.

With changing fertilizer demand, tobacco producers have the option of applying $\mathrm{K}$ in broadcast applications before transplanting, banded applications at or just after transplanting, or in banded applications split at transplanting and layby (roughly 4-6 wk after transplanting). Each method has advantages and disadvantages that must be considered.

Banded, sidedress applications between transplanting and layby are common in most flue-cured tobacco operations (Tso, 1990c). Banded applications of $\mathrm{K}$ after transplanting are common because the nutrient is placed near the root zone, thus improving use efficiency. Research conducted by Collins and Hawks (1993) shows a slight yield increase in band applications of $\mathrm{K}$ over broadcast applications. Band applications can be made anytime between transplanting and layby, with common applications being one or two bands at transplanting, one band $10 \mathrm{~d}$ after transplanting, or a split application of equal rates at transplanting and layby. Split applications of $\mathrm{K}$ were found to be more efficient than one single band application on soil types that are highly leachable (San Valentin et al., 1978).

Broadcast application of complete fertilizers on flue-cured tobacco is no longer a common practice due to the risk of fertilizer salt damage from N placement (Tso, 1990c; Collins and Hawks, 1993). As a result of alternative fertilizer programs and to improve

Abbreviations: OTRS, Oxford Tobacco Research Station; UAN, urea ammonium nitrate; UCPRS, Upper Coastal Plain Research Station. 
Table I. Soil series, soil taxonomic class, soil pH, P index, and $\mathrm{K}$ index at each location.

\begin{tabular}{|c|c|c|c|c|c|}
\hline Location & Soil series & Soil taxonomic class & $\mathrm{pH}+$ & P Index $†$ & K Indext \\
\hline & & & & $\mathrm{mg} \mathrm{dm} \mathrm{m}^{3}$ & $\mathrm{cmol}_{\mathrm{c}} \mathrm{kg}^{-}$ \\
\hline UCPRS-09 & Goldsboro loamy sand & fine-loamy, siliceous, subactive, thermic Aquic Paleudults & 6.2 & 45.6 & 0.25 \\
\hline OTRS-09§ & Helena sandy loam & fine, mixed, semiactive, thermic Aquic Hapludults & 5.8 & 49.2 & 0.19 \\
\hline UCPRSI-IOT & Norfolk loamy sand & fine-loamy, kaolinitic, thermic Typic Kandiudults & 5.8 & 162 & 0.30 \\
\hline UCPRS2-IO\# & Goldsboro loamy sand & fine-loamy, siliceous, subactive, thermic Aquic Paleudults & 6.0 & II2.8 & 0.45 \\
\hline
\end{tabular}

$\dagger$ Soil chemistry represents the upper $20 \mathrm{~cm}$ of the soil profile.

$\ddagger$ Upper Coastal Plain Research Station in 2009.

§ Oxford Tobacco Research Station in 2009.

TI Upper Coastal Plain Research Station in 2010.

\# Upper Coastal Plain Research Station in 2010.

operating efficiency, growers have begun to broadcast $\mathrm{K}$ before forming plant beds and in some cases before fumigation. Soil fumigants are typically applied in the raised bed about 3 to $5 \mathrm{wk}$ before transplanting. Allowing for uniform application before bedding, K application must take place a significant amount of time before transplanting as well. In the time between $\mathrm{K}$ application and transplanting, there is potential for $\mathrm{K}$ to leach out of the rooting zone. The practice of broadcast application of $\mathrm{K}$ fertilizer is also an option for producers who do not apply soil fumigants. Potassium fertilizer can be broadcast and land can be prepared by creating beds just before transplanting. In both situations, the producers' intentions are to complete the $\mathrm{K}$ application before transplanting, therefore reducing workloads as the season progresses. The broadcast application of $\mathrm{K}$ fits very well with new fertilizer programs that apply $\mathrm{N}$ and $\mathrm{K}$ independently to reduce risk of salt injury.

Past research provides inadequate details as to when and how to apply $\mathrm{K}$ in different management systems. With newer, alternative fertilizer plans now being implemented by growers, information is needed to provide accurate $\mathrm{K}$ recommendations. The objective of this study was to determine if alternative application methods of $\mathrm{K}$ are acceptable in tobacco production, and to determine their effect on application rate.

\section{METHODS AND MATERIALS}

\section{Field Procedures}

The experiments were conducted at the Upper Coastal Plain Research Station (UCPRS) near Rocky Mount, NC, and the Oxford Tobacco Research Station (OTRS) in Oxford, NC, in 2009 and at two separate locations at the UCPRS in 2010 (designated as UCPRS-1 and UCPRS-2). An additional test site at OTRS in 2010 was lost to the disease tobacco mosaic virus (TMV). Test sites were selected based on soil type, soil texture, and proximity to major flue-cured tobacco production regions (Table 1). Individual plots were four rows wide by $12.19 \mathrm{~m}$ long, with all four rows treated and the two center rows harvested for yield and quality. Individual plant spacing was 55 by $122 \mathrm{~cm}$. Cultivars used in this study were NC 71 (Goldleaf Seed Company, Hartsville, SC) at the UCPRS and NC 297 (Goldleaf Seed Company, Hartsville, SC) at the OTRS. Different cultivars were selected because of their popularity among producers (Fisher et al., 2009) and because of the need for specific disease resistance at both locations (Mila and Radcliff, 2011). Tobacco was produced using recommendations from the North Carolina Cooperative Extension Service, except for treatments imposed. Cured tobacco was weighed for yield and assigned a USDA government grade. Each government grade has an associated grade index value which describes the leaf maturity and ripeness (Bowman et al., 1988). Additionally, each USDA grade has an associated monetary value; this value was multiplied by crop yield to establish overall crop value.

\section{Field Conditions}

Field conditions (soil series, soil taxonomic class, pH, P-Index, and K-Index) and monthly rainfall are described by location in Tables 1 and 2. Treatments included 0, 84, 140, 196, and $252 \mathrm{~kg} \mathrm{~K}_{2} \mathrm{O} \mathrm{ha}^{-1}$. Each rate was applied either broadcast 1 mo before transplanting, broadcast $1 \mathrm{wk}$ before transplanting, banded at planting, or banded with one-half rate at transplanting and one-half rate at layby. Potassium application timings were chosen to represent different crop management programs for producers. Applications made 1 mo before transplanting represent production systems in which producers would be applying a soil fumigant. Soil fumigants are applied roughly 1 mo before transplanting to avoid crop injury. Alternatively, applications made $1 \mathrm{wk}$ before transplanting represent production systems where producers do not have a need to apply soil fumigants. Broadcast applications of $\mathrm{K}$ fertilizer occur before the formation of raised plant beds. Full rate applications made at transplanting as well as half-rate applications made at transplanting and half-rate applications made at layby are standard production practices which are common throughout tobacco-producing regions in the United States.

Transplanting dates, fertilizer application dates, and tissue sampling dates at each location are described in Table 3. Broadcast applications were made by hand before transplanting and

Table 2. Monthly total precipitation from pretransplant to harvest at each location.

\begin{tabular}{|c|c|c|c|c|}
\hline Month & $\begin{array}{c}\text { UCPRS- } \\
2009 \dagger\end{array}$ & $\begin{array}{l}\text { OTRS- } \\
2009 \ddagger\end{array}$ & $\begin{array}{c}\text { UCPRSI - } \\
2010 \S\end{array}$ & $\begin{array}{c}\text { UCPRS2 } \\
20109\end{array}$ \\
\hline March & I8.I & 12.7 & 20.0 & 20.0 \\
\hline April & 2.0 & 2.1 & 2.8 & 2.8 \\
\hline May & 8.7 & 18.4 & 13.2 & 13.2 \\
\hline June & 9.1 & 11.3 & 3.2 & 3.2 \\
\hline July & 8.9 & 6.4 & 5.4 & 5.4 \\
\hline August & 7.4 & 8.1 & 11.3 & 11.3 \\
\hline September & 12.1 & 1.0 & 26.2 & 26.2 \\
\hline October & 3.5 & 2.8 & 3.9 & 3.9 \\
\hline Total & 69.8 & 62.8 & 86.0 & 86.0 \\
\hline
\end{tabular}

$\dagger$ Upper Coastal Plain Research Station in 2009.

$\ddagger$ Oxford Tobacco Research Station in 2009.

$\S$ Upper Coastal Plain Research Station in 2010.

II Upper Coastal Plain Research Station in 2010. 
Table 3. Dates for transplanting, fertilizer application, and tissue sampling at each location.

\begin{tabular}{|c|c|c|c|c|c|c|c|c|}
\hline \multirow[b]{2}{*}{ Location } & \multirow[b]{2}{*}{ Transplanting } & \multicolumn{4}{|c|}{ Fertilizer application } & \multicolumn{3}{|c|}{ Tissue sampling } \\
\hline & & $\begin{array}{c}\text { Broadcast I } \\
\text { mo }\end{array}$ & $\begin{array}{c}\text { Broadcast } \\
\text { I wk }\end{array}$ & $\begin{array}{c}\text { Banded at } \\
\text { transplanting }\end{array}$ & $\begin{array}{c}\text { Banded at } \\
\text { layby }\end{array}$ & Layby & Topping & After curing \\
\hline UCPRS-09† & 29 Apr. & 30 Mar. & 22 Apr. & 29 Apr. & 18 June & 18 June & I6 July & 15 Sept. \\
\hline OTRS-09‡ & 21 May & 21 Apr. & I4 May & 2I May & 25 June & 25 June & 31 July & 31 July \\
\hline UCPRSI-IO§ & 27 Apr. & 25 Mar. & 13 Apr. & 27 Apr. & 4 June & 4 June & 28 June & 10 Nov. \\
\hline UCPRS2-I0I & 27 Apr. & 25 Mar. & 13 Apr. & $27 \mathrm{Apr}$ & 4 June & 4 June & 28 June & 10 Nov. \\
\hline
\end{tabular}

† Upper Coastal Plain Research Station in 2009.

‡Oxford Tobacco Research Station in 2009.

$\S$ Upper Coastal Plain Research Station in 2010.

Tा Upper Coastal Plain Research Station in 2010.

Table 4. Composite soil analysis of plots not receiving supplemental potassium.

\begin{tabular}{|c|c|c|c|c|c|}
\hline $\begin{array}{c}\text { Test site and } \\
\text { sampling interval }\end{array}$ & $\begin{array}{c}\text { Sampling } \\
\text { date }\end{array}$ & Depth & $\mathbf{P}$ & $\mathbf{K}$ & Mg \\
\hline & & $\mathrm{cm}$ & $\mathrm{mg} \mathrm{dm}-3$ & $-\mathrm{cmol}_{c}$ & $\mathrm{ckg}^{-1}$ \\
\hline \multirow[t]{2}{*}{ UCPRS-09† I mo } & 30 Mar. & $0-15$ & 45.6 & 0.34 & 1.08 \\
\hline & & $15-30$ & 67.9 & 0.29 & 0.81 \\
\hline \multirow[t]{2}{*}{ UCPRS-09† I wk } & 22 Apr. & $0-15$ & 88.8 & 0.40 & 1.20 \\
\hline & & $15-30$ & 42.7 & 0.22 & 0.98 \\
\hline \multirow[t]{2}{*}{ UCPRS-09† planting } & 29 Apr. & $0-15$ & 84.3 & 0.30 & 0.85 \\
\hline & & $15-30$ & 71.7 & 0.23 & 0.85 \\
\hline \multirow[t]{2}{*}{ UCPRS-09† layby } & 18 June & $0-15$ & 94.0 & 0.31 & 0.93 \\
\hline & & $15-30$ & 99.5 & 0.22 & 0.87 \\
\hline \multirow[t]{2}{*}{ OTRS-09 I mo } & 2I Apr. & $0-15$ & 159.6 & 0.19 & 0.60 \\
\hline & & $15-30$ & 121.5 & 0.17 & 0.69 \\
\hline \multirow[t]{2}{*}{ OTRS-09 I wk } & I 4 May & & 129.9 & 0.19 & 0.63 \\
\hline & & $15-30$ & 114.3 & 0.17 & 0.61 \\
\hline \multirow[t]{2}{*}{ OTRS-09 $\ddagger$ planting } & 2I May & $0-15$ & 155.8 & 0.17 & 0.54 \\
\hline & & $15-30$ & 139.9 & 0.15 & 0.48 \\
\hline \multirow[t]{2}{*}{ OTRS-09¥ layby } & 25 June & $0-15$ & 152.7 & 0.13 & 0.53 \\
\hline & & $15-30$ & 149 & 0.15 & 0.51 \\
\hline \multirow[t]{2}{*}{ UCPRSI-IO§ I mo } & 25 Mar. & $0-15$ & 219.7 & 0.30 & 1.16 \\
\hline & & $15-30$ & 192.4 & 0.26 & 0.64 \\
\hline \multirow[t]{2}{*}{ UCPRSI-IO§ I wk } & 13 Apr. & $0-15$ & 212.2 & 0.37 & 1.20 \\
\hline & & $15-30$ & 197.1 & 0.28 & 0.72 \\
\hline \multirow[t]{2}{*}{ UCPRSI-IO§ planting } & 27 Apr. & $0-15$ & 200.1 & 0.44 & 1.51 \\
\hline & & $15-30$ & 225.7 & 0.29 & 0.78 \\
\hline \multirow[t]{2}{*}{ UCPRSI-IO§ layby } & 4 June & $0-15$ & 186.2 & 0.28 & 1.06 \\
\hline & & $15-30$ & 220.5 & 0.23 & 0.55 \\
\hline \multirow[t]{2}{*}{ UCPRS2-I0TI I mo } & 25 Mar. & $0-15$ & 115.6 & 0.32 & 0.99 \\
\hline & & $15-30$ & 50.0 & 0.28 & 0.69 \\
\hline \multirow[t]{2}{*}{ UCPRS2-I0ף I wk } & I 3 Apr. & $0-15$ & 122.8 & 0.30 & 0.97 \\
\hline & & $15-30$ & 78.8 & 0.31 & 0.69 \\
\hline \multirow[t]{2}{*}{ UCPRS2-I0I planting } & 27 Apr. & $0-15$ & 151.3 & 0.41 & 1.27 \\
\hline & & $15-30$ & 138.1 & 0.30 & 0.68 \\
\hline \multirow[t]{2}{*}{ UCPRS2-I0ף layby } & 4 June & $0-15$ & 150.9 & 0.30 & 1.00 \\
\hline & & $15-30$ & 93.4 & 0.29 & 0.61 \\
\hline
\end{tabular}

† Upper Coastal Plain Research Station in 2009.

¥ Oxford Tobacco Research Station in 2009.

$\S$ Upper Coastal Plain Research Station in 2010.

T Upper Coastal Plain Research Station in 2010.

incorporated into the soil using a field cultivator. Posttransplanting applications were made with a single band application which was $12 \mathrm{~cm}$ away from the plant and 12-cm deep. Band applications were placed into a furrow created with a 140 Farmall tractor (Case International Harvester, Racine, WI). Following K application treated furrows were closed with single row rolling cultivators.

Tissues samples were collected at three growth stages: layby (when plants were roughly $38 \mathrm{~cm}$ tall), topping (just after flower was removed), and after curing (weighted composite sample of all four harvested stalk positions). Sampling intervals were chosen because of the critical times they represent during the growing season. Layby occurs 4 to $6 \mathrm{wk}$ after transplanting and is the last opportunity tobacco producers have to make fertilizer applications. Topping occurs 8 to $10 \mathrm{wk}$ after transplanting and is the time when $\mathrm{K}$ deficiencies are most often observed. Cured leaf samples were collected to determine final nutrient content. Soil samples were collected from two depths $(15$ and $30 \mathrm{~cm})$ at four separate intervals: 1 mo before transplanting, $1 \mathrm{wk}$ before transplanting, at planting, and at layby. Soil sampling dates for each interval are described in Table 4.

All K was supplied as sulfate of potash magnesia (0-0-22) (K-Mag, The Mosaic Company, Plymouth, MN). Sulfate of potash magnesia also supplied $\mathrm{Mg}(11 \%)$ and S (22\%), and rates were chosen that ensured adequate amounts of both nutrients for plant use. Nitrogen was supplied in split applications from 30\% urea ammonium nitrate (UAN) applied at a total rate of $78 \mathrm{~kg} \mathrm{~N} \mathrm{ha}^{-1}$ at the UCPRS and from calcium nitrate (15.5-0-0) applied at a total rate of $67 \mathrm{~kg} \mathrm{~N} \mathrm{ha}^{-1}$ at the OTRS.

\section{Analytical Procedures}

Total Alkaloids and Reducing Sugars

Total alkaloids and reducing sugars were determined by the Noth Carolina State University Tobacco Analytical Services Lab on campus. Fifty-gram cured leaf samples were prepared for each plot by compositing cured leaf from each stalk position on a weighted-mean basis. Oven-dried samples were ground to pass through a 1-mm sieve and analyzed for percent total alkaloids and percent reducing sugars using the method of Davis (1976).

\section{Nitrogen, Phosphorus, Potassium, and Magnesium}

Percent $\mathrm{N}$ in the leaf tissue was determined by dry combustion using the method of Plank (1992) using a PerkinElmer PE 2400 elemental analyzer (PerkinElmer Inc., Waltham, MA). Percent P, $\mathrm{K}$, and $\mathrm{Mg}$ in the leaf tissue was determined using the method of Plank (1992) using a PerkinElmer Optima 2000 DV elemental analyzer (PerkinElmer Inc., Waltham, MA).

\section{Soil Samples}

Soil samples were analyzed at the North Carolina Department of Agriculture and Consumer Services Agronomic Lab in Raleigh, NC. Samples were analyzed for $\mathrm{P}, \mathrm{K}, \mathrm{Ca}, \mathrm{Mg}, \mathrm{S}, \mathrm{Na}, \mathrm{Mn}, \mathrm{Cu}$, and $\mathrm{Zn}$ by means of Mehlich-3 extractant using inductively coupled argon plasma spectroscopy on a volume basis (Mehlich, 1984a). Cation exchange capacity (CEC) was determined by summation of basic cations (excluding $\mathrm{Na}$ ) and buffer acidity (Mehlich et al., 1976). Soil 
Table 5. Probability > F values for yield, quality, value, total alkaloids, reducing sugars, and elemental leaf content.

\begin{tabular}{|c|c|c|c|c|c|c|}
\hline Variable & $\begin{array}{c}\text { Location } \times \text { Rate } \times \\
\text { Application }\end{array}$ & $\begin{array}{c}\text { Rate } \times \\
\text { Application }\end{array}$ & Location $\times$ Rate & $\begin{array}{l}\text { Location } \times \\
\text { Application }\end{array}$ & Rate & Application \\
\hline Yield & 0.8086 & 0.8236 & $0.0202^{*}$ & 0.9788 & $0.0361 *$ & 0.9900 \\
\hline Grade index & 0.5649 & 0.5869 & 0.7780 & 0.6872 & 0.5591 & 0.5936 \\
\hline Crop value & 0.9429 & 0.8971 & 0.2356 & 0.9067 & 0.4577 & 0.6332 \\
\hline Total alkaloids & 0.4944 & 0.4184 & 0.0528 & 0.1010 & 0.9177 & 0.6730 \\
\hline Reducing sugars & 0.3991 & 0.8189 & 0.2936 & 0.1002 & $0.0238 *$ & 0.4340 \\
\hline N-layby & 0.8889 & 0.1214 & 0.4202 & 0.4851 & 0.1477 & 0.5720 \\
\hline N-topping & 0.9713 & 0.9809 & 0.3896 & 0.3775 & 0.9573 & 0.0643 \\
\hline $\mathrm{N}$-after curing & 0.7740 & 0.5395 & 0.3187 & 0.5575 & 0.0964 & 0.9103 \\
\hline P-layby & 0.5589 & 0.6626 & 0.2123 & 0.9247 & 0.1385 & 0.1125 \\
\hline P-topping & 0.3110 & 0.1928 & 0.7479 & $0.0204^{*}$ & 0.5022 & 0.1264 \\
\hline P-topping-UCPRS-09 & - & 0.7555 & - & - & 0.4261 & 0.1200 \\
\hline P-topping-OTRS-09 & - & 0.1544 & - & - & 0.7869 & 0.0891 \\
\hline P-topping-UCPRSI-I0 & - & 0.7926 & - & - & 0.4195 & 0.1995 \\
\hline P-topping-UCPRS2-I0 & - & 0.8363 & - & - & 0.1546 & 0.0658 \\
\hline P-after curing & 0.9443 & 0.5425 & 0.5239 & 0.5852 & 0.3129 & $0.0323 *$ \\
\hline K-layby & 0.7917 & 0.1237 & 0.6114 & $0.0015^{*}$ & 0.0584 & 0.3047 \\
\hline K-topping & 0.4049 & 0.5651 & 0.6321 & $0.0343 *$ & 0.4800 & 0.1848 \\
\hline K-after curing & 0.4558 & 0.7495 & $0.0319 *$ & 0.3898 & $<0.0001 *$ & 0.1847 \\
\hline Mg-layby & 0.3930 & 0.4213 & 0.2272 & 0.1936 & $0.0054^{*}$ & $0.0101 *$ \\
\hline Mg-topping & 0.3574 & 0.4499 & 0.6098 & 0.1131 & 0.6051 & 0.2137 \\
\hline Mg-after curing & 0.2069 & 0.5926 & 0.5374 & 0.2082 & $0.0113 *$ & 0.1435 \\
\hline
\end{tabular}

* Significant at the 0.05 probability level.

$\mathrm{pH}$ was determined on a 1:1 soil/water volume ratio. Humic matter determinations were made using a $\mathrm{NaOH}$ digestion with colorimetric determination (Mehlich, 1984b).

\section{Statistical Analysis}

Treatments were replicated four times and arranged in a randomized complete block design. Data for crop yield, crop quality, crop value, percent total alkaloids, percent reducing sugars, and elemental leaf content were subjected to ANOVA using the PROC GLM procedure in SAS (SAS version 9.1, SAS Institute, Cary, NC). Treatment means were separated using Fisher's Protected LSD test at $p \leq 0.05$.

\section{RESULTS}

A significant location effect was noted across all parameters because of varying soil types and growing conditions; however, the interaction of location $\times$ rate $\times$ application method was not significant and data are pooled where appropriate (Table 5).

\section{Physical Characteristics, Chemical Characteristics, and Crop Value}

\section{Yield}

The response of leaf yield to increasing rates of $\mathrm{K}_{2} \mathrm{O}$ was different at one location (Table 5). The only location that demonstrated a yield response was the 2009 OTRS site, a trend is difficult to establish based on application rate alone, but a response was observed as rates were increased to $252 \mathrm{~kg} \mathrm{~K}_{2} \mathrm{O} \mathrm{ha}{ }^{-1}$ at this site (Table 6). At all other locations, $0 \mathrm{~kg} \mathrm{~K}_{2} \mathrm{O} \mathrm{ha}^{-1}$ was adequate. The lack of response to additional units of $\mathrm{K}_{2} \mathrm{O}$ is possibly due to soils having medium to high residual $\mathrm{K}$ (Table 1 ), which is common on $>60 \%$ of tobacco producing soils in the state (Smith, 2011), as well as adequate soil moisture throughout the growing season (Table 2).
Table 6. Yield response to increasing rates of $\mathrm{K}_{2} \mathrm{O}$ across all treatments at individual locations. $\dagger$

\begin{tabular}{|c|c|c|c|c|}
\hline $\mathbf{K}_{2}$ O Rate & $\begin{array}{c}\text { UCPRS- } \\
09 \ddagger\end{array}$ & $\begin{array}{c}\text { OTRS- } \\
09 \S\end{array}$ & $\begin{array}{c}\text { UCPRS I - } \\
\text { I0 }\end{array}$ & $\begin{array}{c}\text { UCPRS2- } \\
\text { I0\# }\end{array}$ \\
\hline \multicolumn{5}{|c|}{$-\mathrm{kg} \mathrm{ha}{ }^{-1}$} \\
\hline 0 & $3364 a$ & $3428 \mathrm{ab}$ & $3374 a$ & $3260 \mathrm{a}$ \\
\hline 84 & $3331 \mathrm{a}$ & $3252 b$ & $34 I \mathrm{Ia}$ & $3405 a$ \\
\hline 140 & $3239 a$ & $3385 a b$ & $3387 a$ & $3404 a$ \\
\hline 196 & $3183 a$ & $3234 b$ & $3514 a$ & $3206 a$ \\
\hline 252 & $3126 a$ & $3644 a$ & $3627 a$ & $3422 a$ \\
\hline
\end{tabular}

† Means followed by the same letter within the same category are not significantly different.

‡ Upper Coastal Plain Research Station in 2009.

§ Oxford Tobacco Research Station in 2009.

II Upper Coastal Plain Research Station in 2010.

\# Upper Coastal Plain Research Station in 2010.

\section{Grade Index}

The quality of cured tobacco was not significantly affected by increasing application rates of $\mathrm{K}_{2} \mathrm{O}$ from 0 to $252 \mathrm{~kg} \mathrm{~K}_{2} \mathrm{O} \mathrm{ha}^{-1}$ (Tables 5 and 7). Results are similar to those from Chaplin and Miner (1980) and Collins and Hawks (1993) that did not consistently find a correlation between $\mathrm{K}_{2} \mathrm{O}$ rate and leaf quality when rates in excess of those needed for maximum yield were used.

\section{Crop Value}

The value of cured tobacco was not affected by increasing rates of $\mathrm{K}_{2} \mathrm{O}$ (Tables 5 and 7). Results are similar to Collins and Hawks (1993) who could not establish a correlation between increased rates of $\mathrm{K}_{2} \mathrm{O}$ and leaf quality, which would increase value.

\section{Total Alkaloids}

Total alkaloid accumulation in cured leaves was not affected by $\mathrm{K}_{2} \mathrm{O}$ rate (Tables 5 and 7 ). Results are similar to those by Woltz et 
Table 7. Physical and chemical response to increasing rates of $\mathrm{K}_{2}$ O. Data are pooled over all locations. $\dagger$

\begin{tabular}{|c|c|c|c|c|}
\hline $\mathrm{K}_{2} \mathrm{O}$ rate & $\begin{array}{l}\text { Grade } \\
\text { index } \neq\end{array}$ & Value & $\begin{array}{c}\text { Total } \\
\text { alkaloids§ }\end{array}$ & $\begin{array}{c}\text { Reducing } \\
\text { sugars§ }\end{array}$ \\
\hline $\mathrm{kg} \mathrm{ha}^{-1}$ & & $\$ \mathrm{ha}^{-1}$ & $\longrightarrow$ & 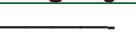 \\
\hline 0 & $80 a$ & I I287a & $4.06 a$ & $12.39 \mathrm{ab}$ \\
\hline 84 & $79 a$ & $10502 a$ & $4.04 a$ & $12.65 \mathrm{a}$ \\
\hline 140 & $79 a$ & $10500 \mathrm{a}$ & $4.07 a$ & $11.97 a b$ \\
\hline 196 & $79 a$ & $10588 \mathrm{a}$ & $4.08 a$ & II.78b \\
\hline 252 & $78 a$ & $10914 a$ & $4.06 a$ & $11.84 b$ \\
\hline
\end{tabular}

$\dagger$ Means followed by the same letter within the same category are not significantly different.

$\ddagger$ Grade index is a measure of tobacco quality on a ranking scale of I to 100 , with 100 having the highest quality.

$\S$ Total alkaloid and reducing sugar data were collected from a weighted composite sample of all four harvested stalk positions.

al. (1949), Elliot (1968), and Chaplin and Miner (1980) who could not establish a correlation between increased rates of $\mathrm{K}_{2} \mathrm{O}$ and total alkaloid content. Total alkaloids are typically only influenced by $\mathrm{K}_{2} \mathrm{O}$ rate when a corresponding yield affect is observed (Leggett et al., 1977; Chaplin and Miner, 1980).

\section{Reducing Sugars}

Reducing sugar content was affected by increasing rates of $\mathrm{K}_{2} \mathrm{O}$ (Table 5). As rates of $\mathrm{K}_{2} \mathrm{O}$ increased, the reducing sugar content of cured tobacco slightly decreased (Table 7); however, reducing sugar content is within the established range for flue-cured tobacco. These findings are in conflict with Woltz et al. (1949), Elliot (1968), Chaplin and Miner (1980), and Tso (1990a) who could not establish a correlation between increased rates of $\mathrm{K}_{2} \mathrm{O}$ and reducing sugar content.

\section{Elemental Leaf Content}

Elemental leaf content for $\mathrm{N}, \mathrm{P}, \mathrm{K}$, and $\mathrm{Mg}$ was measured at three separate intervals during the growing season: at layby, at topping, and after curing.

\section{Nitrogen}

Neither application method or application rate of $\mathrm{K}_{2} \mathrm{O}$ had an effect on total $\mathrm{N}$ content in leaf tissue at any sampling interval (Table 5). This is in conflict with Tso (1990a) who reported that as rates of $\mathrm{K}_{2} \mathrm{O}$ increase, total $\mathrm{N}$ content is decreased. Overall, additional $\mathrm{K}$ did not decrease the uptake of $\mathrm{N}$ from the soil which would have decreased overall $\mathrm{N}$ content in plant tissue.

\section{Phosphorus}

Application method of $\mathrm{K}_{2} \mathrm{O}$ had a significant effect on $\mathrm{P}$ content in leaf tissue at topping when all locations are pooled (Table 5); however, once each test site was analyzed individually effects are not significant (Table 5). Application method of $\mathrm{K}_{2} \mathrm{O}$ also had a significant effect on $\mathrm{P}$ content in leaf tissue after curing (Table 5). The range of $\mathrm{P}$ content after curing was 0.21 to $0.24 \%$ (data not shown), which is not agronomically significant because $\mathrm{P}$ content at each interval is above established deficiency level of $0.12 \%$ for leaf tissue (Campbell, 2009) and therefore was not a limiting factor.

\section{Potassium}

An application method response was observed at all sampling intervals at UCPRS2-10 (Tables 5 and 8). Alternatively, a rate response in $\mathrm{K}$ leaf content was observed after curing at three locations (Tables 5 and 9). Establishing a trend for application methods is difficult where a response was observed; however, $\mathrm{K}$ content tends to increase when the nutrient is applied closer to transplanting (Table 8). Potassium rate had a significant effect on elemental leaf content after curing at UCPRS-09, OTRS-09, and UCPRS1-10 (Table 9). Elemental $\mathrm{K}$ content tends to increases as rates of $\mathrm{K}_{2} \mathrm{O}$ increase to $196 \mathrm{~kg} \mathrm{~K}_{2} \mathrm{O} \mathrm{ha}^{-1}$ (Table 9). Overall, $\mathrm{K}$ content was sufficient at all rates and application methods to maximize yield (Tables 8 and 9), and elemental leaf content at each interval was above the established deficiency level of $1.00 \%$ (Flower, 1999). No visual $\mathrm{K}$ deficiency symptoms were observed in this study, thus furthering the justification for lower rates of applied $\mathrm{K}$. The results are in agreement with Chaplin and Miner (1980) who determined that $\mathrm{K}$ content in cured tobacco leaves increased as rates of $\mathrm{K}_{2} \mathrm{O}$ increased.

Table 8. Leaf $\mathrm{K}$ content by application method at layby, topping, and after curing at individual locations. $\dagger$

\begin{tabular}{|c|c|c|c|c|c|c|c|c|c|c|c|c|}
\hline \multirow[b]{2}{*}{$\begin{array}{c}\text { Application } \\
\text { method }\end{array}$} & \multicolumn{3}{|c|}{ UCPRS-09 $\ddagger$} & \multicolumn{3}{|c|}{ OTRS-09§ } & \multicolumn{3}{|c|}{ UCPRSI-I0I } & \multicolumn{3}{|c|}{ UCPRS2-I 10\# } \\
\hline & Layby & Topping & $\begin{array}{l}\text { After } \\
\text { curing }\end{array}$ & Layby & Topping & $\begin{array}{l}\text { After } \\
\text { curing }\end{array}$ & Layby & Topping & $\begin{array}{l}\text { After } \\
\text { curing }\end{array}$ & Layby & Topping & $\begin{array}{l}\text { After } \\
\text { curing }\end{array}$ \\
\hline $\begin{array}{l}\text { None } \\
\text { appliedt† }\end{array}$ & $4.32 \mathrm{a}$ & $2.17 a$ & $2.42 a$ & $3.1 \mathrm{la}$ & $1.87 \mathrm{a}$ & I.48a & $3.62 a$ & $2.5 \mathrm{la}$ & $2.23 a$ & $3.86 \mathrm{~d}$ & $2.4 \mathrm{Ic}$ & $2.15 c$ \\
\hline BC-IM㧊 & $4.69 a$ & $2.4 \mathrm{Ia}$ & $2.52 \mathrm{a}$ & $3.65 a$ & $3.90 \mathrm{a}$ & $2.35 a$ & $4.02 \mathrm{a}$ & $2.67 a$ & $2.33 a$ & $4.08 \mathrm{~cd}$ & $2.77 \mathrm{~b}$ & $2.25 \mathrm{bc}$ \\
\hline BC-IW $\S \S$ & $4.72 \mathrm{a}$ & $2.60 \mathrm{a}$ & $2.60 \mathrm{a}$ & $3.79 \mathrm{a}$ & $2.97 a$ & $2.30 \mathrm{a}$ & $4.08 \mathrm{a}$ & $2.54 a$ & $2.25 \mathrm{a}$ & $4.15 b c$ & $2.87 \mathrm{~b}$ & $2.43 a b$ \\
\hline APशा & $4.65 a$ & $2.60 \mathrm{a}$ & $2.52 a$ & $3.59 a$ & $3.25 \mathrm{a}$ & $2.32 \mathrm{a}$ & $4.14 a$ & $2.99 \mathrm{a}$ & $2.48 \mathrm{a}$ & $4.38 a b$ & $3.28 \mathrm{a}$ & $2.47 a b$ \\
\hline Split\#\# & $4.67 a$ & $2.59 a$ & $2.66 a$ & $3.53 a$ & $3.15 \mathrm{a}$ & $2.29 a$ & $4.03 a$ & $2.67 \mathrm{a}$ & $2.4 \mathrm{la}$ & $4.45 a$ & $3.22 \mathrm{a}$ & $2.53 a$ \\
\hline
\end{tabular}

† Means followed by the same letter within the same category are not significantly different.

¥ Upper Coastal Plain Research Station in 2009.

§ Oxford Tobacco Research Station 2009.

I Upper Coastal Plain Research Station 2010.

\# Upper Coastal Plain Research Station 2010.

†† None applied $=$ control where $0 \mathrm{~kg} \mathrm{~K}_{2} \mathrm{O} \mathrm{ha-1}$ was applied.

怙C-IM = all potassium broadcast applied I mo before transplanting.

$\S \S B C-I W=$ all potassium broadcast applied I wk before transplanting.

ITा $A P=$ all potassium band applied at transplanting.

\#\# Split = all potassium band applied at one-half rate at transplanting and one-half rate 4 to $6 \mathrm{wk}$ later. 
Table 9. Leaf $\mathrm{K}$ content response to increasing rates of $\mathrm{K}_{2} \mathrm{O}$ after curing at individual locations. $\dagger$

\begin{tabular}{|c|c|c|c|c|}
\hline $\mathrm{K}_{2} \mathrm{O}$ rate & $\begin{array}{c}\text { UCPRS- } \\
09 \ddagger\end{array}$ & $\begin{array}{c}\text { OTRS- } \\
09 \S\end{array}$ & $\begin{array}{c}\text { UCPRSI- } \\
\text { I0ף }\end{array}$ & $\begin{array}{c}\text { UCPRS2- } \\
\text { I0\# }\end{array}$ \\
\hline $\mathrm{kg} \mathrm{ha}^{-1}$ & & $\%$ & & \\
\hline 0 & $2.4 \mathrm{Ib}$ & $1.48 \mathrm{c}$ & $2.22 b$ & $2.15 \mathrm{a}$ \\
\hline 84 & $2.37 \mathrm{~b}$ & $2.13 b$ & $2.13 b$ & $2.40 \mathrm{a}$ \\
\hline 140 & $2.53 \mathrm{ab}$ & $2.36 \mathrm{ab}$ & $2.32 \mathrm{ab}$ & $2.37 \mathrm{a}$ \\
\hline 196 & $2.80 \mathrm{a}$ & $2.29 a b$ & $2.63 a$ & $2.43 a$ \\
\hline 252 & $2.59 \mathrm{ab}$ & $2.48 a$ & $2.39 \mathrm{ab}$ & $2.47 a$ \\
\hline
\end{tabular}

$\dagger$ Means followed by the same letter within the same category are not significantly different.

¥ Upper Coastal Plain Research Station in 2009.

§ Oxford Tobacco Research Station in 2009.

TI Upper Coastal Plain Research Station in 2010

\# Upper Coastal Plain Research Station in 2010.

\section{Magnesium}

At layby, both application rate of potassium magnesium sulfate and application method had a significant effect on elemental $\mathrm{Mg}$ leaf content (Table 5). As rates of applied potassium magnesium sulfate increased $\mathrm{Mg}$ leaf content increased; however, the range of $\mathrm{Mg}$ content was 0.52 to $0.57 \%$ (data not shown) which does not have an agronomic impact on the crop. Potassium magnesium sulfate applied at planting contained the highest amount of $\mathrm{Mg}$ in leaf tissue with $0.57 \%$ (data not shown); all other intervals contained 0.52 to $0.55 \%$ (data not shown). After curing, leaf $\mathrm{Mg}$ content was only affected by application rate of potassium magnesium sulfate (Table 5). Magnesium content in the cured leaf was not significantly improved above $140 \mathrm{~kg} \mathrm{~K}_{2} \mathrm{O} \mathrm{ha}^{-1}$. The range of $\mathrm{Mg}$ content after curing was 0.60 to $0.63 \%$ (data not shown), which is not agronomically significant because the nutrient was not limiting and leaf tissue from plots with the lowest $\mathrm{Mg}$ content were above the established deficiency level of $0.15 \%$ (Tso, 1990b).

\section{Soil Analysis}

\section{Soil Analysis}

Soil samples were only taken from plots receiving $0 \mathrm{~kg} \mathrm{~K}_{2} 0 \mathrm{ha}^{-1}$ and sampling occurred each time $\mathrm{K}$ applications were made to other plots. Two samples were taken, one from 0 to $15 \mathrm{~cm}$ and another from 15 to $30 \mathrm{~cm}$. Soil samples were not statistically analyzed because they were not taken across all treatments; however, it is worth noting the data for each test site. Variability in soil fertility was observed across all locations (Table 4). Although there are no specified critical nutrient levels for tobacco, it is possible that Piedmont soils with $<30 \mathrm{~g} \mathrm{~m}^{-3}$ of P and Coastal Plain soils with $<50 \mathrm{~g} \mathrm{~m}^{-3}$ of $\mathrm{P}$ may exhibit deficiency symptoms without supplemental fertilization (Hardy et. al., 2012). Soils with $<0.50 \mathrm{cmol}_{\mathrm{c}} \mathrm{kg}^{-1}$ of $\mathrm{K}$ and $0.25 \mathrm{cmol}_{\mathrm{c}} \mathrm{kg}^{-1}$ of $\mathrm{Mg}$ may also exhibit deficiencies when no supplemental fertilizer is applied (Hardy et. al., 2012). Soil samples taken from control plots during research were used to make generalizations about individual test site characteristics.

For all test sites, soil $\mathrm{P}$ and $\mathrm{Mg}$ levels were sufficient for optimum tobacco growth for the entire season (Table 4). Before transplanting at UCPRS-09 soil P levels were below the critical level; however, at the time of transplanting soil $\mathrm{P}$ was adequate (Table 4). Visual P and Mg deficiency symptoms were not observed at any test site. Soil K levels were below the previously mentioned limit of $0.50 \mathrm{cmol}_{\mathrm{c}} \mathrm{kg}^{-1}$ at all test sites (Table 4); however, visual deficiency symptoms were not observed. Soil fertility was adequate all season for the respective nutrients.

\section{DISCUSSION}

Application method and application timing had no significant agronomic effect on yield, quality, value, or any measured leaf constituents. In both years, crop quality was not affected by application rate and application method, thus demonstrating that under conditions present at test sites alternative application methods are acceptable. Leaf yield demonstrated a favorable response to $252 \mathrm{~kg} \mathrm{~K}_{2} \mathrm{O} \mathrm{ha}^{-1}$ at OTRS-09; however, at all other locations $0 \mathrm{~kg} \mathrm{~K}_{2} \mathrm{O} \mathrm{ha}{ }^{-1}$ was enough to produce favorable yields with all other measured parameters remaining unaffected. The $0 \mathrm{~kg} \mathrm{~K}_{2} \mathrm{O} \mathrm{ha}^{-1}$ rate is adequate, but according to the state soil testing lab a minimum rate of $84 \mathrm{~kg} \mathrm{~K}_{2} \mathrm{O} \mathrm{ha}^{-1}$ would be recommended to overcome the possibility of unfavorable growing conditions as well as to prevent the mining of soil nutrients. Under the environmental conditions of these experiments, $84 \mathrm{~kg} \mathrm{~K}_{2} \mathrm{O}$ ha $^{-1}$ applied broadcast 1 mo before planting, broadcast at planting, banded at planting, or applied in split applications provided adequate amounts of $\mathrm{K}$ to ensure sufficient yield and quality at all locations. It is likely that early broadcast applications of $\mathrm{K}_{2} \mathrm{O}$ with current rate recommendations would only be of concern with combinations of conditions that included coarse soil textures, low residual soil $\mathrm{K}$, and/or excessive leaching rainfall.

Soil texture and depth to clay have a major impact on $\mathrm{K}$ application rates, and both must be considered. Test sites for this study were selected based on soil type and texture, and these characteristics had a significant effect on crop response to $\mathrm{K}$ application. The loss of $\mathrm{K}^{+}$is also of concern on coarsetextured soils similar to the Norfolk soil series at UCPRS-1. Coarse textured soils have lower cation exchange capacities and monovalent cations are often lost from the rooting zone in the event of leaching rainfall. However, if the depth to clay is $<25 \mathrm{~cm}$ it is likely that $\mathrm{K}^{+}$lost to leaching is held in the clay subsoil where it can be used once adequate root growth has occurred. It is advisable for producers to take soil samples down to $25 \mathrm{~cm}$ to provide a reasonable estimate of the nutrient content in the soil. Subsoil $\mathrm{K}$ that remains unaccounted for is the reason why responses to $\mathrm{K}$ application are not observed, even when a soil test indicates it should. Additionally, coarse-textured soils have difficulty maintaining adequate soil moisture during periods of drought or extended dry conditions. Soil moisture facilitates diffusion of the $\mathrm{K}^{+}$ion from the point of application to the root zone, and in the absence of adequate moisture diffusion is greatly inhibited.

The considerations of soil texture and depth to clay are extremely important when making $\mathrm{K}$ recommendations and fit very well with reports from Denton et al. (1987). Denton et al. (1987) report findings similar to those from this study for flue-cured tobacco produced across a variety of soil textures. Optimum rates of $\mathrm{K}_{2} \mathrm{O}$ were found to differ significantly among Fertility Capability Classification (FCC) soil groups; however, the highest optimum rates were on soils with a sand or loamy sand surface where the $\mathrm{A}$ and $\mathrm{E}$ horizons were $>0.5 \mathrm{~m}$ thick (Denton et al., 1987). Alternatively, the lowest optimum K rates reported by Denton et al. (1987) were on soils with thin, loamy surfaces, which indicate a relatively shallow depth to clay. As previously mentioned, $\mathrm{K}^{+}$can leach from the upper soil profile when cation exchange capacity is low, such as with a sandy topsoil; however, if 
the depth to clay is $<25 \mathrm{~cm}$ it is likely that $\mathrm{K}^{+}$lost to leaching is held in the clay subsoil where it can be used once adequate root growth has occurred. The subsoil $\mathrm{K}$ is more accessible to tobacco plants on soils with thin, loamy surfaces than on soils with thick, sandy surfaces due to the increased depth to the B horizon (Denton et al., 1987). Ultimately, responses to increased rates of $\mathrm{K}_{2} \mathrm{O}$ would be expected under these conditions as a result of compensation for the loss of $\mathrm{K}^{+}$due to leaching.

Additionally, the independent application of K works extremely well for producers using alternative fertility programs. As mentioned previously, additional application of $\mathrm{P}$ is not necessary on $85 \%$ of the soils used for tobacco production in the state (Smith, 2011), and as a result producers can decouple complete $\mathrm{N}-\mathrm{P}-\mathrm{K}$ fertilizers and apply $\mathrm{N}$ and $\mathrm{K}$ independently of one another. This has allowed producers to explore alternate sources for both nutrients. Sulfate of potash magnesia fertilizer $(0-0-22)$ has gained popularity as a result of it being a cheaper source of $\mathrm{K}$ than when supplied in a complete fertilizer and because of the additional $\mathrm{Mg}$ and $S$ it supplies. Also, as a part of alternative fertility programs, liquid N (28\% UAN, 30\% UAN, and 32\% UAN) sources are now being implemented as the only source of $\mathrm{N}$ for the entire growing season by many producers. Liquid $\mathrm{N}$ sources are often cheaper than other $\mathrm{N}$ sources used in tobacco production, and are easier to apply for producers with experience applying them to other crops.

\section{CONCLUSION}

Applying $\mathrm{K}_{2} \mathrm{O}$ independent of other nutrients, as done in this study, fits extremely well with alternative fertilizer plans that fluecured tobacco producers are now implementing. Furthermore, lower $\mathrm{K}$ recommendations and alternative fertilizer management plans are suitable for producers when both residual soil $\mathrm{K}$ as well as soil texture are considered. Early broadcast applications of $\mathrm{K}_{2} \mathrm{O}$ with current rate recommendations would only be of concern with combinations of conditions that included coarse soil textures, low $\mathrm{K}$ indices, and/or excessive leaching rainfall. There is great potential for producers on fine- or medium-textured soils to reduce $\mathrm{K}_{2} \mathrm{O}$ rates and apply $\mathrm{K}_{2} \mathrm{O}$ through different methods without limiting yield and quality, thus reducing workloads and creating larger returns.

\section{REFERENCES}

Bowman, D.T., A.G. Tart, E.A. Wernsman, and T.C. Corbin. 1988. Revised North Carolina grade index for flue-cured tobacco. Tob. Sci. 32:39-40.

Campbell, C.R. 2009. Harvesting tobacco based on tissue analysis. North Carolina Dep. of Agriculture and Consumer Serv., Raleigh. www.ncagr.gov/ agronomi/pdffiles/tobaccopta703.pdf (accessed 2 June 2011).

Chaplin, J.F., and G.S. Miner. 1980. Production factors affecting the chemical components of the tobacco leaf. In: R.H. Martin et al., editors. The 34th Tobacco Chemists' Research Conference: Chemical, Physical, and Production Aspects of Tobacco and Smoke, Richmond, VA. 27 Oct. 1980. North Carolina State Univ., Raleigh. p. 3-63.

Collins, W.K., and S.N. Hawks. 1993. Fertilization. In: W.K. Collins and S.N. Hawks, editors, Principles of flue-cured tobacco production. 3rd ed. Hawks and Collins, Raleigh, NC. p. 97-140.
Davis, R.E. 1976. A combined automated procedure for the determination of reducing sugars and nicotine alkaloids in tobacco products using a new reducing sugar method. Tob. Sci. 20:139-144.

Denton, H.P., G.F. Peedin, S.N. Hawks, and S.W. Buol. 1987. Relating the fertility capability classification system to tobacco response to potassium fertilization. Soil Sci. Soc. Am. J. 51:1224-1228. doi:10.2136/ sssaj1987.03615995005100050024x

Elliot, J.M. 1968. Effect of applied potassium on certain agronomic, chemical, and physical characteristics of flue-cured tobacco. Tob. Sci. 12:151-157.

Fisher, L.R., W.D. Smith, G. Tart, and K. Barnes. 2009. Selecting a variety. In: L.R. Fisher, editor, North Carolina State University: Flue-cured tobacco guide 2009. AG-187 (Revised ed.). North Carolina Coop. Ext., Raleigh. p. 19-43.

Flower, K.C. 1999. Field practices. In: L.D. Davis, and M.T. Nielson, editors, Tobacco: Production, chemistry, and technology. Blackwell Sci., London. p.76-103.

Hardy, D.H., M.R. Tucker, and C.E. Stokes. 2012. Crop fertilization based on North Carolina Soil Tests Circular no. 1. North Carolina Dep. of Agric. and Consumer Serv., Raleigh. www.ncagr.gov/agronomi/pdffiles/obook.pdf (accessed 29 Oct. 2012).

Huang, W. 2012. Fertilizer use and price. USDA, Washington, DC. www.ers. usda.gov/Data/FertilizerUse/ (accessed 6 July 2012).

Leggett, J.E., J.L. Sims, D.R. Gossett, U.R. Pal, and J.F. Benner. 1977. Potassium and magnesium nutrition effects on yield and chemical composition of burley tobacco leaves and smoke. Can. J. Plant Sci. 57:159-166. doi:10.4141/ cjps77-023

Mehlich, A. 1984a. Mehlich-3 soil test extractant: A modification of Mehlich-2 extractant. Commun. Soil Sci. Plant Anal. 15(12):1409-1416. doi:10.1080/00103628409367568

Mehlich, A. 1984b. Photometric determination of humic matter in soils, a proposed method. Commun. Soil Sci. Plant Anal. 15(12):1409-1416. doi:10.1080/00103628409367568

Mehlich, A., S.S. Bowling, and A.L. Hatfield. 1976. Buffer $\mathrm{pH}$ acidity in relation to nature of soil acidity and expression of lime requirement. Commun. Soil Sci. Plant Anal. 7(3):253-263. doi:10.1080/00103627609366638

Mila, M., and J. Radcliff. 2011. Managing diseases. In: L.R. Fisher, editor, North Carolina State University: Flue-cured tobacco guide 2011. AG-187 (Revised ed.). North Carolina Coop. Ext., Raleigh. p. 133-166.

Plank, C.O. (1992). Plant analysis reference procedures for the southern region of the united states. (No. 368). The Georgia Agric. Exp. Stations and College of Agric. and Environ. Sciences, Athens.

Raper, C.D., and C.B. McCants. 1967. Nutrient accumulation in flue-cured tobacco. Tob. Sci. 10:109.

San Valentin, G.O., W.K. Robertson, J.T. Johnson, and W.W. Weeks. 1978. Effect of slow release fertilizer on fertilizer residues and on yield and composition of flue-cured tobacco. Agron. J. 70:345-348. doi:10.2134/agronj1978.000219 $62007000020030 \mathrm{x}$

Sims, J.L. 1985. Potassium nutrition of tobacco. In: R.D. Munson, editor, Potassium in agriculture. ASA, CSSA, and SSSA, Madison, WI. p. 1023-1043.

Smith, W.D. 2011. Managing nutrients. In: L.R. Fisher, editor, North Carolina State University: Flue-cured tobacco guide 2011. AG-187 (Revised ed.). North Carolina Coop. Ext., Raleigh. p. 67-82.

Tso, T.C. 1990a. Interrelationship among plant-leaf-smoke. In: T.C. Tso, editor, Production, physiology, and biochemistry of tobacco plant. IDEALS, Inc., Beltsville, MD. p. 3-32.

Tso, T.C. 1990b. Nutrition-minor elements and heavy metals. In: T.C. Tso, editor, Production, physiology, and biochemistry of tobaco plant. IDEALS, Inc., Beltsville, MD. p. 313-368.

Tso, T.C. 1990c. Soil and fertilizer. In: T.C. Tso, editor, Production, physiology, and biochemistry of tobacco plant. IDEALS, Inc., Beltsville, MD P. 75-82.

Woltz, W.G., W.A. Reid, and W.E. Colwell. 1949. Sugar and nicotine in cured bright tobacco as related to mineral element composition. Soil Sci. Soc. Am. J. 13:385-387. doi:10.2136/sssaj1949.036159950013000C0069x 